\title{
SURF Framework for a Sustainable Economy
}

\author{
Marilyn Waite ${ }^{1}$ \\ ${ }^{1}$ Sustainability Practitioner, France \\ Correspondence: Marilyn Waite, Issy-les-Moulneaux, France. E-mail: marilyn.waite@cantab.net
}

Received: May 16, 2013

Accepted: June 1, $2013 \quad$ Online Published: November 15, 2013

doi:10.5539/jms.v3n4p25

URL: http://dx.doi.org/10.5539/jms.v3n4p25

\begin{abstract}
This article presents a practical framework for approaching sustainable development and the green economy. As a result of analyzing the on-the-ground reality of attempting to transform products and services for sustainable development, the author identified gaps and incoherencies that rendered a new framework necessary. The SURF framework: supply chain, user, relations, and future, enables a systems-level approach, and subsequently a systems-level impact, for decisions made even on a very microscopic level. Start-ups and large companies, public organizations and private ones alike will benefit from adopting this framework and adapting it to their unique needs. The framework was configured based on an extensive analysis of available definitions, understandings, and methods for implementing sustainable development on a concrete level, as well as through discussions with various industries. A sample product in the form of a t-shirt, manufactured from bamboo textiles, is used to explain the application of SURF. SURF moves beyond the triple-bottom-line approach to sustainable development to place emphasis on the quadruple bottom line.
\end{abstract}

Keywords: blue economy, business, circular economy, framework, functional economy, future generations, green economy, supply chain, sustainability, sustainable development

\section{Introduction}

Although the foundations of sustainable development and sustainability are as old as our ancient civilizations, the twenty-first century has seen an urgent push to couple economic growth and stability with sustainability thinking. There have emerged numerous definitions of what it means to develop sustainably and what the end-goal of sustainability might entail. Consumers, in particular, have demanded products and services that give good value for money, respect the environment, and adhere to corporate social responsibility standards. Fair trade labels, organic stores, food miles, carbon footprint, and other phenomena have arisen in the backdrop of a global movement in sustainable development. For those attempting to translate the broad definitions of sustainable development into real transformation for a product, service, result, process, or entire organization, there are two extremes. On the one hand, practitioners find that theoretical literature has very macroscopic ideas for sustainable development and sustainability (Table 1). On the other hand, there is a large body of specific tools such as life cycle analysis that can enable sustainable development decision-making (Table 2). When trying to determine how to design company " $\mathrm{x}$ " as a sustainable one, the practitioner must be able to merge these two extremes. The SURF framework provides a streamlined method that encompasses both ends.

The most commonly quoted definition of sustainable development is that of the World Commission on Environment and Development, or the Bruntland report. However, there are shared themes among the various definitions including economic, environmental and social rights of the present and future generations. As some of the understandings of sustainable development in Table 1 indicate, translating definitions into practise can prove difficult, especially with competing demands and tradeoffs. The "green economy" terminology has been introduced by international organizations to place emphasis on the need to transform the economy in order to move towards sustainable development; the green economy is defined by the United Nations Environment Programme as one that results in improved human well-being and social equity, while significantly reducing environmental risks and ecological scarcities (UNEP). The present practise of becoming a more sustainable business or organization tends to focus on what is being sold or offered to the end-user. What is often missing is (1) the entire life cycle supply chain that makes up the item being offered, (2) the end user itself (what happens with the product or service once it is delivered), (3) positive relations with all stakeholders connected to and impacted by the offer, and (4) a product or service that is mindful of future generations. 
Table 1. Definitions and understandings of sustainable development*

\begin{tabular}{|c|c|c|}
\hline Author & Definition/Interpretation & Source \\
\hline Worthington, 1938 & $\begin{array}{l}\text { A key problem was how Homo sapiens could himself benefit from the vast ecological } \\
\text { complex which was Africa, how he could live and multiply on the income of the natural } \\
\text { resources without destroying their capital... and how he could conserve the values of } \\
\text { Africa for future generations, not only the economic values but also the scientific and } \\
\text { ethical ones. }\end{array}$ & (Worthington, 1938) \\
\hline Conway, 1987 & $\begin{array}{l}\text { The net productivity of biomass (positive mass balance per unit area per unit time) } \\
\text { maintained over decades to centuries. }\end{array}$ & (Elliott, 2006) \\
\hline WCED, 1987 & $\begin{array}{l}\text { Sustainable development is development that meets the needs of the present, without } \\
\text { compromising the ability of future generations to meet their own needs. }\end{array}$ & $\begin{array}{l}\text { (World Commission on } \\
\text { Environment and } \\
\text { Development, 1987) }\end{array}$ \\
\hline Barbier, 1987 & It is indistinguishable from the total development of society. & (Elliott, 2006) \\
\hline Turner, 1988 & $\begin{array}{l}\text { In principle, such an optimal (sustainable growth) policy would seek to maintain an } \\
\text { "acceptable" rate of growth in per-capita real incomes without depleting the national } \\
\text { capital asset stock or the natural environmental asset stock. }\end{array}$ & (Elliott, 2006) \\
\hline IISD, 1992 & $\begin{array}{l}\text { For the business enterprise, sustainable development means adopting business strategies } \\
\text { and activities that meet the needs of the enterprise and its stakeholders today while } \\
\text { protecting, sustaining and enhancing the humanand natural resources that will be needed } \\
\text { in the future. }\end{array}$ & $(\mathrm{IISD}, 1992)$ \\
\hline Solow, 1993 & An obligation to leave behind a generalized capacity to create well-being. & (Solow, 1993) \\
\hline O'Riordan, 1995 & Its very ambiguity enables it to transcend the tensions inherent in its meaning. & (Elliott, 2006) \\
\hline Mitchel, 1997 & A creatively ambiguous phrase... an intuitively attractive but slippery concept. & (Elliott, 2006) \\
\hline Redclift, 1997 & $\begin{array}{l}\text { Like motherhood, and God, it is difficult not to approve of it. At the same time, the idea of } \\
\text { sustainable development is fraught with contradictions. }\end{array}$ & (Elliott, 2006) \\
\hline Mawhinney, 2001 & Sustainable development appears to be an over-used misunderstood phrase. & $($ Elliott, 2006) \\
\hline Maathai, 2006 & $\begin{array}{l}\text { In trying to explain this linkage, I was inspired by a traditional African tool that has three } \\
\text { legs and a basin to sit on. To me the three legs represent three critical pillars of just and } \\
\text { stable societies. The first leg stands for democratic space, where rights are respected, } \\
\text { whether they are human rights, women's rights, children's rights, or environmental rights. } \\
\text { The second represents sustainable and equitable management and resources. And the third } \\
\text { stands for cultures of peace that are deliberately cultivated within communities and } \\
\text { nations. The basin, or seat, represents society and its prospects for development. Unless all } \\
\text { three legs are in place, supporting the seat, no society can thrive. Neither can its citizens } \\
\text { develop their skills and creativity. When one leg is missing, the seat is unstable; when two } \\
\text { legs are missing, it is impossible to keep any state alive; and when no legs are available, } \\
\text { the state is as good as a failed state. No development can take place in such a state either. } \\
\text { Instead, conflict ensues. }\end{array}$ & (Maathai, 2007) \\
\hline $\begin{array}{l}\text { Rio }+20 \text { UN } \\
\text { Conference on } \\
\text { Sustainable } \\
\text { Development, } 2012\end{array}$ & $\begin{array}{l}\text { We recognize that poverty eradication, changing unsustainable and promoting sustainable } \\
\text { patterns of consumption and production and protecting and managing the natural resource } \\
\text { base of economic and social development are the overarching objectives of and essential } \\
\text { requirements for sustainable development. }\end{array}$ & (United Nations, 2012) \\
\hline
\end{tabular}

Note: *This is not an exhaustive list; there are understandings of sustainable development that predate the $1930 \mathrm{~s}$.

\section{Conceptual Framework}

The work leading to the SURF approach entailed an in-depth literature review and examination of company approaches to sustainable development, which resulted in the identification of gaps between theory and practice. Table 2 indicates the sustainable development tools, methods, frameworks, and guidelines examined. Twenty in-person interviews were conducted with adults from various sectors (science and technology, health, education, law and policy, entertainment and media, and business and economics) in order to clarify the practices of sustainable development in various fields. The primary questions asked were how each person defined sustainability and sustainable development, and how they believed that this applied to their current workplace, current company, and current industry. The qualitative interviews helped the author identify potential gaps between talking about sustainable development and acting on it within organizations. Based on an analysis of the requirements of sustainable development, across various definitions and applications, the author developed the SURF framework and proposes its use for ensuring that products and services, whether for a large company or small non-profit organization, are aligned to the major tenets of sustainable development. In addition to the interviews and analysis of existing work, the author tested the rationale of the framework based on (1) in-depth 
knowledge gained from academically studying sustainable development at the postgraduate level and (2) work experience gained in various organizations and sectors (international development, industry, research, technology start-ups, etc.) and in various subject matters (energy, textiles, food and nutrition, water, education, etc.).

SURF stands for supply chain considerations that address sustainability criteria; user considerations that address sustainability criteria; relations with employees, colleagues, the surrounding community, and society at large; and concern for future generations. Social, environmental, and economic concerns underlie each element of SURF, with future planning also receiving adequate attention. Successful implementation of the SURF framework is dependent on planning and utilization of the most effective tools. Table 2 provides a list of tools, international standards and guidelines, and indices that were analyzed as a basis for the SURF framework.

Table 2. Specific tools, guidelines, frameworks, and indices for sustainable development decision-making*

\begin{tabular}{|c|c|}
\hline Tool/Method Name & Description \\
\hline Backcasting & $\begin{array}{l}\text { A way of planning in which a successful outcome is imagined in the future, followed by the question: } \\
\text { "what do we need to do today to reach that successful outcome?" (The Natural Step). }\end{array}$ \\
\hline Carbon Footprinting & $\begin{array}{l}\text { Calculating the total amount of greenhouse gases that are emitted into the atmosphere each year by a } \\
\text { person, family, building, organization, or company (USEPA). }\end{array}$ \\
\hline Ecological Footprinting & $\begin{array}{l}\text { Calculating how much area of biologically productive land and water an individual, population or activity } \\
\text { requires to produce all the resources it consumes and to absorb the waste it generates, using prevailing } \\
\text { technology and resource management practices (Global Footprint Network, 2011). }\end{array}$ \\
\hline Lean Manufacturing & $\begin{array}{l}\text { The process of analyzing the flow of information and materials in a manufacturing environment and } \\
\text { continuously improving the process to achieve enhanced value for the customer. Lean is a systematic } \\
\text { approach to identifying and eliminating waste (non-value-added activities) through continuous } \\
\text { improvement by flowing the product at the pull of the customer (Wisconsin Manufacturing Extension } \\
\text { Partnership). }\end{array}$ \\
\hline Life Cycle Analysis/Assessment & $\begin{array}{l}\text { A technique to assess the environmental aspects and potential impacts associated with a product, } \\
\text { process, or service, by:compiling an inventory of relevant energy and material inputs and environmental } \\
\text { releases, evaluating the potential environmental impacts associated with identified inputs and releases, } \\
\text { and interpreting the results to help you make a more informed decision (USEPA, 2012). }\end{array}$ \\
\hline Water Footprinting & $\begin{array}{l}\text { Calculating the total volume of freshwater used to produce the goods and services consumed by the } \\
\text { individual or community or produced by a business. Water use is measured in terms of water volumes } \\
\text { consumed (evaporated or incorporated into a product) and/or polluted per unit of time (Hoekstra, 2011). }\end{array}$ \\
\hline $\begin{array}{l}\text { International Standards and } \\
\text { Guidelines }\end{array}$ & Description \\
\hline Global Sullivan Principles & $\begin{array}{l}\text { Principles for company endorsement which shows support for universal human rights, equal } \\
\text { opportunity for employees at all levels of the company, employees' voluntary freedom of association, } \\
\text { compensation that allows employees to meet at least their basic needs and provide the opportunity to } \\
\text { improve their skill and capability, a safe and healthy workplace, protection of human health and the } \\
\text { environment, sustainable development, fair competition, and civil engagement (Leon H. Sullivan } \\
\text { Foundation). }\end{array}$ \\
\hline Global Reporting Initiative & $\begin{array}{l}\text { Indicators are organized into categories: Economic, Environmental and Social. The Social category is } \\
\text { broken down further by Labor, Human Rights, Society and Product Responsibility } \\
\text { subcategories.Principles for defining report content include materiality, stakeholder inclusiveness, } \\
\text { sustainability context, and completeness. Principles for ensuring report quality include balance, } \\
\text { comparability, accuracy, timelines, clarity, and reliability (Global Reporting Initiative). }\end{array}$ \\
\hline AA1000 Guidelines & $\begin{array}{l}\text { In addition to financial accountability, the AA1000 standard includes the principles of (1) inclusivity } \\
\text { (the requirement to reflect the needs and concerns of all stakeholders in all stages of the social and } \\
\text { ethical accounting, auditing, and reporting process), (2) completeness, materiality, regularity and } \\
\text { timeliness, (3) quality assurance, and (4) embeddedness and continuous improvement (AccountAbility). }\end{array}$ \\
\hline $\begin{array}{l}\text { ISO } 14000 \text { Series, } 9000 \text { Series, } \\
26000 \text {, and Other }\end{array}$ & See ISO Table (Note 1) (International Organization for Standardization) \\
\hline $\begin{array}{l}\text { Guidelines for Multinational } \\
\text { Enterprises }\end{array}$ & $\begin{array}{l}\text { Recommendations addressed by governments to multinational enterprises operating in or from adhering } \\
\text { countries. They provide voluntary principles and standards for responsible business conduct in areas } \\
\text { such as employment and industrial relations, human rights, environment, information disclosure, } \\
\text { combating bribery, consumer interests, science and technology, competition, and taxation (OECD, } \\
\text { 2011). }\end{array}$ \\
\hline Global Compact & $\begin{array}{l}\text { Consists of } 10 \text { principles: businesses should (1) support and respect the protection of internationally } \\
\text { proclaimed human rights (2) make sure that they are not complicit in human rights abuses, (3) uphold }\end{array}$ \\
\hline
\end{tabular}


the freedom of association and the effective recognition of the right to collective bargaining, (4) eliminate all forms of forced and compulsory labor, (5) abolish child labor, (6) eliminate discrimination in respect of employment and occupation, (7) support a precautionary approach to environmental challenges, (8) undertake initiatives to promote greater environmental responsibility, (9) encourage the development and diffusion of environmentally friendly technologies, and (10) work against corruption in all its forms, including extortion and bribery (United Nations).

Responsible Care Global Charter Chemical industry's global initiative that drives continuous improvement in health, safety and environmental performance, together with open and transparent communication with stakeholders. Responsible Care embraces the development and application of sustainable chemistry (International Council of Chemical Associations, 2013).

World Business Council for The WBCSD Framework has three components: the Measuring Impact Framework Methodology, Sustainable Development Guidelines Beyond the Bottom Line (company case studies), and an Excel User Guide that helps companies carry out an assessment. The Measuring Impact Framework consists of four steps: step 1 is to set boundaries, step 2 is to measure direct and indirect impacts, step 3 is to assess contribution to development, and step 4 is to prioritize management response. The business activities are grouped into four clusters: governance and sustainability, assets, people, and financial flows (WBCSD).

Sustainability Integrated Guidelines for Management (SIGMA) Consist of two core elements: (1) the holistic management of five different types of capital that reflect an organization's overall impact and wealth (natural capital, social capital, human capital, manufactured capital, and financial capital), and (2) the exercise of accountability by being transparent and responsive to stakeholders and complying with relevant rules and standards (British Standards Institution, Forum for the Future, and AccountAbility, 200 (Stahel, 1986) (Stahel, 1986)6). SA8000 compliance requires adopting policies and procedures that protect the basic human rights of workers. The management system supports sustainable implementation of the elements of SA8000: child labor, forced and compulsory labor, health and safety, freedom of association and right to collective bargaining, discrimination, disciplinary practices, working hours, and remuneration (Social Accountability International, 2012).

\begin{tabular}{l} 
Frameworks, Concepts and \\
Models \\
\hline Cleaner Production \\
\hline Cradle-to-Cradle
\end{tabular}
Description

The continuous application of an integrated preventative environmental strategy to processes, products and services to increase efficiency and reduce risks to humans and the environment (UNEP, 1991). Concept that "waste" equals "food" in both biological and technicalmaterial flows (McDonough \& Braungart, 2002).

Circular Economy A circular economy seeks to rebuild capital, whether this is financial, manufactured, human, social or natural (Ellen MacArthur Foundation).

Blue Economy The blue economy is where the best for health and the environment is cheapest and the necessities for life are free thanks to a local system of production and consumption that works with what you have (Pauli, 2013).

Functional Economy An economy that optimizes the use (or function) of goods and services and thus the management of existing wealth (goods. knowledge, and nature). The economic objective of the functional economy is to create the highest possible use value for the longest possible time while consuming as few material resources and energy as possible. This functional economy is therefore considerably more sustainable, or dematerialized, than the present economy, which is focused on production and related material flows as its principal means to create wealth (Stahel, 1986).

Green Economy The green economy results in improved human well-being and social equity, while significantly reducing environmental risks and ecological scarcities. In its simplest expression, a green economy can be thought of as one that islow carbon, resource efficientandsocially inclusive (UNEP).

Sustainable Assessment Model Uses 22 performance indicators to measure full lifecycle, environmental, economic and resource usage (SAM) impacts of a project; the impacts are then monetized and can be summed into a single measure called the Sustainability Assessment Model Indicator (SAMi) (Bebbington, 2006).

Sustainability Capital

The Framework for Strategic Sustainable Development
Capital assets are divided into four categories: produced goods or human-made capital $\left(\mathrm{K}_{\mathrm{M}}\right)$, human knowledge and skills or human capital $\left(\mathrm{K}_{\mathrm{H}}\right)$, natural capital $\left(\mathrm{K}_{\mathrm{N}}\right)$, and social capital $\left(\mathrm{K}_{\mathrm{S}}\right)$ (Pearce, 1998). A generic five level framework applied to the "society in the biosphere": (1) Systems Level: Understand, describe and analyze the dynamic relationships between the ecological and social systems, (2) Success Level: In a sustainable society, nature is not subject to systematically increasing concentrations of substances extracted from the Earth's crust, and concentrations of substances produced by society, degradation by physical means; people are not subject to conditions that systematically undermine their capacity to meet their needs, (3) Strategic Guidelines Level: Guidelines for the process of moving global society strategically towards meeting basic principles of socio-ecological sustainability. The practice of backcasting is important to strategic planning, (4) Actions Level: All actions that will effectively help move the global socio-ecological system towards success by conforming to overall strategic principles (includes concrete actions, capacity-building 
efforts, etc.), and (5) Tools Level: Techniques, measurements, monitoring, management approaches, etc. relevant to assist in the global movement towards conformance with basic socio-ecological principles (The Natural Step).

\begin{tabular}{|c|c|}
\hline Indices** & Description \\
\hline Better Life Index & $\begin{array}{l}\text { Allows one to choose the indicators that are most important to them and then rank which location is } \\
\text { better suited to their needs. There are } 11 \text { topics and indicators within each: housing, income, jobs, } \\
\text { community, education, environment, governance, health, life satisfaction, safety, and work-life balance } \\
\text { (OECD). }\end{array}$ \\
\hline Dow Jones Sustainability Index & $\begin{array}{l}\text { The Dow Jones Sustainability Index family tracks the stock performance of companies in terms of } \\
\text { economic, environmental and social criteria. The indices serve as benchmarks for investors who } \\
\text { integrate sustainability considerations into their portfolios, and provide an engagement platform for } \\
\text { companies who want to adopt sustainable best practices (Dow Jones). }\end{array}$ \\
\hline $\begin{array}{l}\text { Environmental Performance } \\
\text { Index }\end{array}$ & $\begin{array}{l}\text { Ranks countries on } 22 \text { performance indicators spanning } 10 \text { policy categories: environmental burden of } \\
\text { disease, water, air pollution effects on human health, air pollution effects on the ecosystem, water } \\
\text { resources, biodiversity and habitat, forestry, fisheries, agriculture and climate change.The precursor to } \\
\text { EPI is ESI, The Environmental Sustainability Index. ESI is a composite index tracking socio-economic, } \\
\text { environmental, and institutional indicators that characterize and influence environmental sustainability } \\
\text { at the national scale (YCELP \& CIESIN, 2012). }\end{array}$ \\
\hline FTSE4Good & $\begin{array}{l}\text { A tool for responsible investors to identify and invest in companies that meet globally recognized } \\
\text { corporate responsibility standards. For inclusion, eligible companies must meetcriteria requirements in } \\
\text { five areas: (1) working towards environmental sustainability, (2) upholding and supporting universal } \\
\text { human rights, (3) ensuring good supply chain labor standards, (4) countering bribery, and (5) mitigating } \\
\text { and adapting to climate change (FTSE, 2010). }\end{array}$ \\
\hline Gross National Happiness Index & $\begin{array}{l}\text { Uses periodic surveys that account for demographical information. Happiness itself is not seen as a } \\
\text { one-dimensional adjective, but rather a multidimensional state that covers nine domains: psychological } \\
\text { wellbeing, time use, community vitality, cultural diversity, ecological resilience, living standard, health, } \\
\text { education, and good governance (Ura, Alkire, Zangmo, \& Wangdi, 2012). }\end{array}$ \\
\hline Human Development Index & Composite index that measures a country's progress in health, knowledge and income (UNDP, 2013). \\
\hline $\begin{array}{l}\text { Genuine Progress Indicator/Index } \\
\text { of Sustainable Economic Welfare }\end{array}$ & $\begin{array}{l}\text { The Index of Sustainable Economic Welfare (ISEW) is an analysis designed by Daly and Cobb that } \\
\text { adjusts GDP to reflect a broader set of social and environmental criteria. ISEW was later revised and } \\
\text { renamed the Genuine Progress Indicator (GPI). In GPI, all values are expressible in monetary units; in } \\
\text { general, additions are made for volunteer work, non-paid household work, services of consumer } \\
\text { durables, services of highways and streets, net capital investment, net foreign lending and borrowing, } \\
\text { and income distribution adjustment, while subtractions are made for crime, family breakdown, } \\
\text { automobile accidents, cost of consumer durables, cost of household pollution abatement, loss of leisure } \\
\text { time, underemployment, commuting, water pollution, air pollution, noise pollution, loss of wetlands, } \\
\text { loss of farmland, resource depletion, long-term environmental damage, ozone depletion, and loss of } \\
\text { old-growth forests (Wilson \& Tyedmers, 2013). The GPI is the total sum of all positive and negative } \\
\text { values expressed in monetary units. The Sustainable Net Benefit Index (SNBI)The SNBI is very similar } \\
\text { to the ISEW and GPI, but the items are sorted into "uncancelled benefit" and "uncancelledcost" accounts; } \\
\text { the SNBI is obtained by subtracting the total of the uncancelled costaccount from the uncancelled benefit } \\
\text { account (Lawn, 2005). }\end{array}$ \\
\hline Sustainable Society Index & $\begin{array}{l}\text { The Sustainable Society Index (SSI) is a measure of sustainability at the national level. The index } \\
\text { includeseight categories (basic needs, health, personal and social development, nature and environment, } \\
\text { natural resources, climate and energy, transition, economy) and twenty-one indicators (Sustainable } \\
\text { Society Foundation). }\end{array}$ \\
\hline
\end{tabular}

Note: *This is not an exhaustive list of tools, guidelines, frameworks, and indices in the sustainable development arena; there are methods specific to various industries and sectors and that heavily focus on one pillar of sustainable development.

**For more indices, see An overview of sustainability assessment methodologies by Singh et al. in Ecological Indicators 15 (2012) 281-299.

Supply chain is one of the most problematic components of transforming organizations. Companies often find it tedious and difficult to perform reliable life cycle analyses of their products. They are also often uncertain about the social and environmental integrity at the most basic level of their supply chain (for example, the suppliers' of the suppliers' of their main suppliers). And although vertically integrated companies can access more intelligence about the inputs to their final product, they often fail to perform full analysis on the supply chains. When organizations do consider supply chain sustainability performance, there is a tendency to focus on the supply chain of the product or service that they are selling but ignore all of the items required to complete the job. For example, for a mining company, the energy performance of a pump that is used to mine ore may be considered in sustainability accounting. However, procuring a pump with the best life cycle environmental 
performance from a socially responsible company may not be studied. For a consulting company, air miles used to conduct business may be considered in carbon calculations, but the pen that consultants use to conduct their work may not be the most "sustainability-friendly."

Another obstacle for organizations seeking to transform for sustainable development is what happens with the product or service once it leaves the organization and enters the hands of the end-user. A computer company can seek to ensure that the materials and labor used to assemble the computer follow sustainability criteria. However, what does the user then do with the computer? Organizations can often fail to consider this end-use and end-of-life step in their sustainability calculations. How is electronic waste dealt with in the market in which the computer is sold? Are there mechanisms to re-use or recycle the components? Are alternative ownership schemes available that would be more in line with sustainable development?

While most organizations realize that people are important, the full range of stakeholders impacted by or somehow connected to the organization can often be neglected. Clients, employees, and regulating bodies are a minimum of actors with which organizations seek to create and maintain positive relations. This would necessarily entail providing quality products to clients on time and on budget, providing fair wages and benefits to employees, and ensuring transparent operations with a regulatory entity. What can often be missing are the communities surrounding the place where the manufacturing or other levels of the product/service activity take place. Full stakeholder engagement tends to take place when there is a major infrastructure project in a location with a strong civil society and accountability mechanisms. However, full stakeholder engagement is necessary at all levels of a project (small and large, at inception and at closing). The Project Management Institute has recently added Stakeholder Management as its tenth knowledge area in the Project Management Body of Knowledge ${ }^{\circledR}$, indicating a shift towards engaging all stakeholders for project managers.

The consideration of future generations is what distinguishes sustainability from other concepts. The environmental movements have sought to create a natural environment whereby we live within the carrying capacity of Earth. The various social movements have sought to guarantee a more just society for all people in all places. The various economic movements, including communist, socialist and capitalist theories, have sought to create an economy whereby the financial well-being of individuals can be assured. However, there is little intrinsic future-focus in the environmental, social and economic campaigns. The here and now can be quite easily the emphasis of these concepts. Sustainable development, however, requires us to act in a future-oriented manner. Surprisingly, it is often this aspect of sustainable development that is left out of sustainability considerations within organizations. Few and far between are backcasting exercises, decisions that take into account multiple generations, and a general reflection on how one's product or service will impact those not yet born.

\section{Framework Example}

This section presents the SURF framework using a bamboo textile t-shirt as an example. Figure 1 presents a graphical representation of SURF, showing that (1) each component: supply chain, user, relations, and future is equally weighted and (2) social, environmental, and economic considerations underlie each SURF component for products, services, results, processes, organizations, and the entire society. 


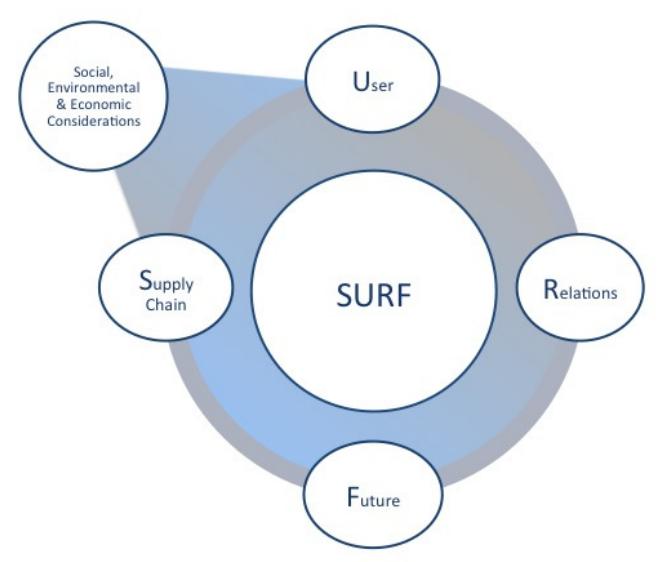

Figure 1. Representation of SURF framework

$\underline{\mathbf{S}}$ stands for all of the things that make up the supply chain of a company's product or service. How do the products in the supply chain measure when it comes to greenhouse gases, water use, energy use, land use, transportation, waste, pollutants, labor, working conditions, and long-term profit? From the components used to assemble a computer to the choice of paper used in a typical office environment, supply chain is arguably the most all-encompassing and challenging sustainability issue to address for an enterprise. Sustainability practitioners often claim that it is difficult to ensure that sustainability objectives are being made throughout the entire value chain. In a globalized economy, company headquarters (where those in charge of corporate social responsibility, environment or sustainability tend to be located) can be far away from the everyday operations of manufacturing of raw materials and products. A quick, announced visit by these practitioners to suppliers may only reveal exceptions to operational practice. However, addressing the supply chain is one way in which everyone can partake in advancing the sustainable development agenda. The demand for more sustainable products at every level of supply will force the entire system to move toward sustainability. Using a bamboo textile t-shirt as an example, companies that sell the t-shirt should require information based on sustainability criteria, for all suppliers involved: raw material sourcing, manufacturers of the fiber, manufacturers of the yarn, manufacturers of the cloth, designers and manufacturers of the t-shirt (Figure 2). Certification schemes can help in this matter, but in the absence of existing certification or in the presence of prohibitory costs for obtaining certification, the receiver of the supply has a responsibility to ask for sustainability information.

Ensuring that a supply chain is economically viable is normally engrained in a company's operations. Through Purchasing Departments and specialist negotiators, organizations ensure that their costs are being optimized. This same rigor should be applied for "greening" the supply chain and ensuring that social and societal values are met (fair wages, no child or slave labor, etc.). The company benefits from better risk management, recognition by both shareholders and different stakeholders, improved image, and long-term viability. Societies as a whole benefit because players are pushed to improve in sustainability criteria and innovate to meet the sustainability demands.

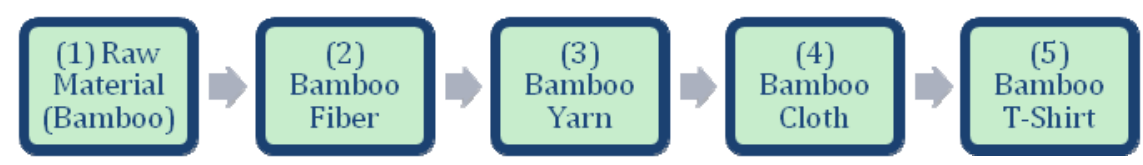

Figure 2. Bamboo textile value chain

(1) Sample Questions for Bamboo Raw Material

- Is the bamboo sustainably harvested (no over-extraction)?

- What is the impact on biodiversity by extracting the bamboo? 
- Is the bamboo certified sustainable by a third-party if certifications exist?

- How much energy is used in obtaining the bamboo (including transportation)?

- How much water is used in growing and obtaining the bamboo?

- How much pollutants are used and generated in growing and obtaining the raw material (including transportation)?

- How is waste dealt with in the process to obtain the bamboo?

- Are sound social and ethical business practices employed (including fair wages and a safe working environment)?

- How is long-term profitability ensured?

(2) Sample Questions for Bamboo Fiber

- Is the most environmentally sound, healthy and safe manufacturing process being used to convert raw bamboo into fiber? For example, are solvents completely recycled to ensure a closed-loop industrial cycle for chemically manufactured bamboo? Can natural enzymes be used to replace chemicals?

- Is the bamboo fiber certified sustainable by a third-party if certifications exist?

- How much energy is used in manufacturing the bamboo fiber (equipment, transportation)?

- How much water is used in manufacturing the bamboo fiber?

- How much pollutants are generated in manufacturing the bamboo fiber (including transportation)?

- How is waste dealt with in the fiber manufacturing process? Is a closed-loop cycle employed?

- Are sound social and ethical business practices employed (including fair wages and a safe working environment)?

- How is long-term profitability ensured?

(3) Sample Questions for Bamboo Yarn

- Is the most environmentally sound, healthy and safe manufacturing process being used to convert fiber into yarn?

- Is the bamboo yarn certified sustainable by a third-party if certifications exist?

- How much energy is used in manufacturing the bamboo yarn (equipment, transportation)?

- How much water is used in manufacturing the bamboo yarn?

- How much pollutants are generated in manufacturing the bamboo yarn (including transportation)?

- How is waste dealt with in the yarn manufacturing process? Is a closed-loop cycle employed (are fiber pieces thrown away)?

- Are sound social and ethical business practices employed (including fair wages and a safe working environment)?

- How is long-term profitability ensured?

(4) Sample Questions for Bamboo Cloth

- Has the most environmentally sound, healthy and safe manufacturing process been used to convert yarn into cloth?

- Is the bamboo cloth certified sustainable by a third-party if certifications exist?

- How much energy is used in manufacturing the bamboo cloth (equipment, transportation)?

- How much water is used in manufacturing the bamboo cloth?

- How much pollutants are generated in manufacturing the bamboo cloth (including transportation)?

- How is waste dealt with in the cloth manufacturing process? Is a closed-loop cycle employed (are cut pieces thrown away)?

- Are sound social and ethical business practices employed (including fair wages and a safe working environment)?

- How is long-term profitability ensured? 
(5) Sample Questions for Bamboo T-shirt

- Has the most environmentally sound, healthy and safe manufacturing process been used to convert cloth into a t-shirt?

- Is the bamboo t-shirt certified sustainable by a third-party if certifications exist?

- How much energy is used in manufacturing the bamboo t-shirt (equipment, transportation)?

- How much water is used in manufacturing the bamboo t-shirt?

- How much pollutants are generated in manufacturing the bamboo t-shirt (including transportation)?

- How is waste dealt with in the t-shirt manufacturing process? Is a closed-loop cycle employed (are cut pieces thrown away)?

- Are sound social and ethical business practices employed (including fair wages and a safe working environment)?

- How is long-term profitability ensured?

$\underline{\mathbf{U}}$ stands for user. What does the user do with the product or service? Do they throw it away immediately to pile up in a landfill? Can it be easily re-used or recycled? Is it biodegradable and have the proper systems been put into place to render that biodegradability useful? Even with the best intentions, sustainability efforts can fall short if the user does not use the product or service in a sustainable manner (or if sustainability systems are unavailable to the user). A recyclable plastic cup is not helping sustainability efforts if the user does not have a recycling system where they are located. An energy efficient light bulb is less "efficient" if the user keeps it on when they are away. A rainwater harvesting system used to provide bathing water is less sustainable if the average bathing quantity is 100 cubic meters of water. Companies can face stumbling blocks for greening products if the users are not properly educated and the appropriate life cycle systems are not put into place to enable users to act for sustainable development. There is an important interaction between the public and private sector for the user. The public sector, through government and civil society, can raise awareness about sustainability responsibility. Government can set the policy framework and provide incentives that make closing industrial and natural cycles more attractive and available for the user. Location is also important. A company whose end-product is in a plastic bottle may encourage "bin" recycling in location $\mathrm{Y}$, where the formal economy dominates, but discourage bin recycling in location $Z$, where the informal economy dominates and whereby people's livelihoods depends on the ability to collect used, "thrown-away" bottles and re-sell them. In either case, since sustainable development is a process, the sustainability goal planning should take into consideration what the user can do with the product. In the case of services, consideration for what the user will do with the service is equally important. Knowledge-sharing is a service that can be misused for harmful means if the proper screening and processes are not in place to protect this misuse.

In the case of the bamboo t-shirt example, one should consider the user's ability to use the t-shirt for a long duration, to use it with little water, energy, chemicals and other pollutants, and to either upcycle the t-shirt or biodegrade it (Figure 3). One hurdle to a sustainable textile industry is the lack of appropriate dedicated textilebiodegrading infrastructure. A t-shirt that may theoretically be biodegradable will have a difficult time doing just that if it is thrown in with a mixture of materials in a general landfill. 


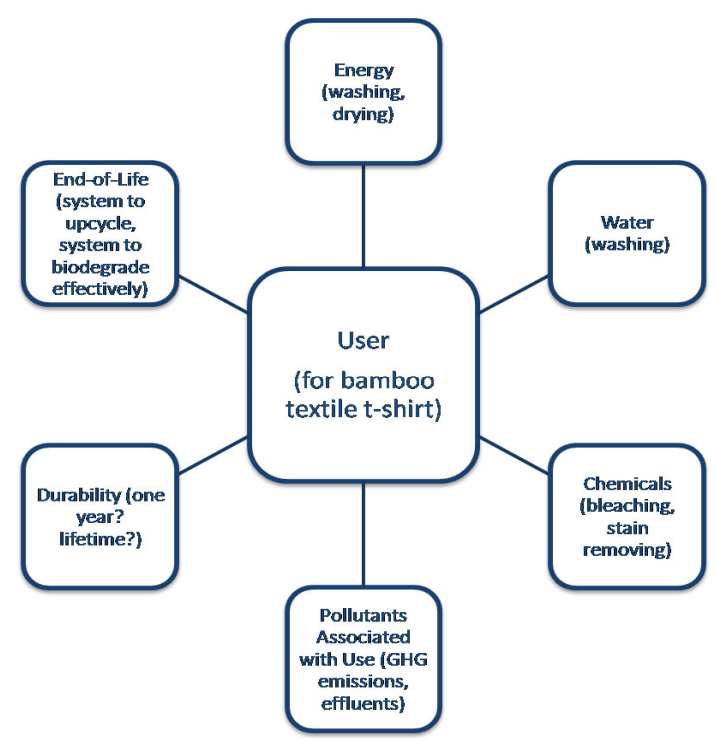

Figure 3. User considerations for a bamboo T-shirt

$\underline{\mathbf{R}}$ stands for relations - both external and internal. Is the work environment healthy and safe for workers? Do employees feel that there is a positive work environment? Are company operations and financing transparent? Do stakeholders participate in decisions that they have an interest in and/or that have an impact on them? Also seen as a risk management tool in the locations where organizations operate, creating and maintaining positive relationships contribute to the sustainability of products and services. This strongly correlates to the societal/social pillar of sustainable development in a very common sense way. Good relations are present if workers are paid fair wages and provided the opportunity to make a positive difference in their community. There are numerous frameworks and theories surrounding satisfaction and motivation (Maslow's hierarchy of needs, Herzberg's Motivator-Hygiene Theory, Theory X, Theory Y and Theory Z, etc.) that should be duly considered in the workplace. While "society" and "social" can be very general words and evoke a number of understandings, "relations" implies at least a two-way communication stream. A relationship involves a sender and a receiver in both directions. This involves stakeholder engagement and community involvement. Figure 4 shows the various relationships to be created and maintained with the bamboo textile t-shirt example in mind.

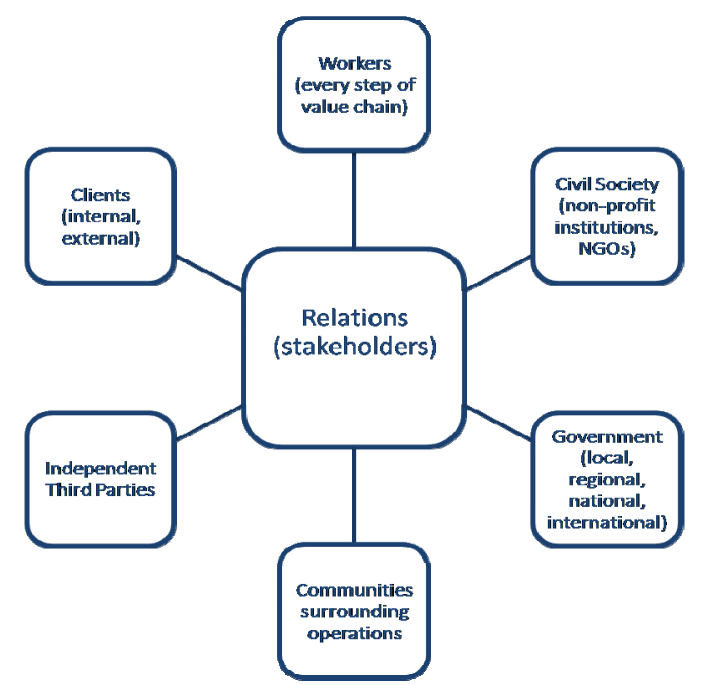

Figure 4. Various positive relationships to create and maintain

F stands for future. The notion that we are responsible to future generations is one that keeps us questioning the 
impact of our operations. Do we have a 10-year plan? Or a 50-year plan? The "triple-bottom-line" (TBL) is often used to convert sustainable development into practical decisions. TBL entails a three-pronged approach of meeting societal/social, environmental and economic needs. However, an equally important and essential aspect of sustainable development is the idea of intergenerational equity, or the quadruple bottom line (QBL). A four-pronged approach, or a four-legged stool is therefore more ideal to bring to the forefront the temporal considerations that sustainable development engenders (Figure 5).

It is long-term thinking that sets sustainable development a part from previous social and environmental considerations. Even if the societal, economic, and ecological implications of a product, service, or decision are taken into account, they can still fail to meet sustainable development goals if only the short-term societal, economic, and ecological implications are considered. So what constitutes long-term or future generations? How far of a vision is required? This will often depend on the industry or topic at hand. In energy predictions, it is customary to think fifty years ahead. The year 2020 is refered to as yesterday, and it is not uncommon to think about 2050 for energy resources and energy mixes of different countries. When running a small restaurant business, fifty years may seem like a long-term outlook. A sustainable development framework requires us to push the limits of whatever the traditional time boundaries may be. Sustainable development requires us to think about the unborn - what the future generations may need and want beyond what is tangible today. It is for that reason that this pillar is often met with unease in reflections about sustainability. Responses such as "I cannot predict the future," and "I do not know what the needs of tomorrow will be" can arise. The intergenerational equity dimension thus underlines the uncertainty in questions about the environmental, social, and economic needs of future generations.

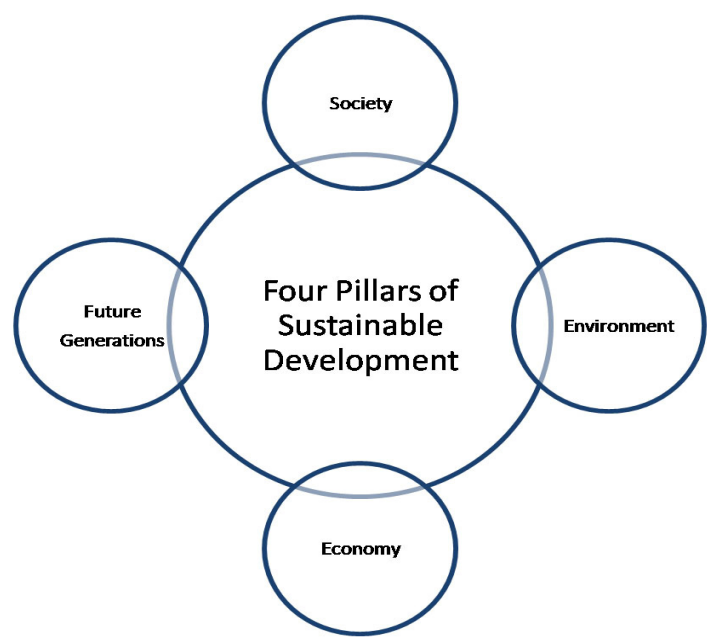

Figure 5. Quadruple Bottom Line (QBL) of sustainable development

\section{Discussion}

There exist different frameworks for sustainable development that align to different end-users (companies, governments, households, etc.) and different contexts (products, public policies, professions, projects, etc.). The SURF framework is a missing link among the current frameworks. It places emphasis on the entire system: the entire supply chain, what happens after the product or service becomes absorbed by the user (and thus the entire life of the product or service), the relationships in each component of the system, and the future generations within the system. It is especially appropriate for implementations that involve tangible objects, due to the supply chain emphasis. However, it is necessary, for example, even for a think tank that is producing mostly ideas and policy suggestions. This think tank will need to make choices about printing its ideas (paper, ink, or digital waste), organizing people (office space and all of the objects involved), travel (associated environmental and social consequences), and the sustainability of the actual ideas.

The SURF framework presented was configured from an educational foundation in sustainable development, professional experience in different sectors, and insights gained from speaking with professionals in a variety of industries. The interviews involved thirteen women and seven men (seven working in science and technology, two working in business and economics, six working in education, two working in health, one working in law 
and policy, one working in food and agriculture, and one working in entertainment and media). Collectively, the data gathered indicated a lack of systems-level and future-oriented thinking for individual companies. While addressing environmental, social, and economic/financial concerns has become a part of corporate culture for many organizations (partly due to international voluntary reporting schemes and some mandatory country-level reporting programs), failure to more fully transform products and services in the green economy has prevailed. By applying the SURF framework, organizations can better perform in sustainability criteria: addressing sustainability throughout the supply chain $(\mathrm{S})$, ensuring that the end-user has a sustainable way in which to use the product or service throughout the life cycle (U), creating and maintaining positive relations with a wide variety of stakeholders (R), and considering the impact of current decisions on future generations (F).

The various definitions and interpretations of sustainable development continue to evolve as indicated in Table 1. Recent emphasis has been placed on the green economy and the circular economy as a way to attain sustainability. While a working definition is essential for public and private institutions to think about how they contribute to sustainable development, definitions do not by themselves provide a practical means for action. Subsequently, various tools, frameworks, and guidelines have been proposed for varying situations as shown in Table 2. The various means to obtain sustainability range from specific calculations for specific environmental impacts (such as carbon dioxide) to wide-ranging indicators such as for gross national happiness. The SURF framework provides a missing framework to ensure a more systems-level sustainable impact geared towards products, services, and organizations.

Future work with the SURF framework may include more examples of its application, as well as comparisons with other sustainable development concepts. Two examples of how SURF can be matched with other frameworks that serve different purposes are shown in the endnotes (Table 3: the civil engineering approach to sustainable development, and Table 4: the mining and metals approach to sustainable development). Future research may analyze the SURF framework's impact on organizations that have implemented it.

Table 3. Crosslinking sustainable development frameworks: civil engineering for sustainable development (Fenner, Ainger, Cruickshank, \& Guthrie, 2006)

Authors Fenner et al have presented an eight-point framework to help guide civil engineering sustainable development. Each of the points is matched to the most relevant SURF elements.

\begin{tabular}{ll}
\hline Framework for Engineers & SURF Matching \\
\hline 1. Ethical Foundation: make value judgements that are guided by a system of ethics & S, U, R, F \\
\hline $\begin{array}{l}\text { 2. Justice Through Participation: understand the real needs for engineering solutions by } \\
\text { encompassing ideas of social equity, equal rights for development, democracy, public participation, } \\
\text { and empowerment }\end{array}$ & \\
\hline $\begin{array}{l}\text { 3. Efficient Coordinated Infrastructure: use efficienct provision and coordination of infrastructure } \\
\text { (allows engineers to work within land use constraints and adopt approaches that link multiple goals }\end{array}$ & \\
of society; for example, mixed-use development, brown field regeneration, preventing construction \\
in flood plains, etc.)
\end{tabular}


Table 4. Crosslinking sustainable development frameworks: mining and metals (ICMM, 2003)

The International Council on Mining and Metals (ICMM) has provided a framework of ten sustainable development principles by which member companies can measure their performance. This framework was benchmarked using the Rio Declaration, Global Reporting Initiative, Global Compact, OECD Guidelines on Multinational Enterprises, World Bank Operational Guidelines, OECD Convention on Combating Bribery, the Voluntary Principles on Security and Human Rights, and various ILO Conventions. Each principle is matched to the most relevant SURF elements.

\begin{tabular}{ll}
\hline Framework for Mining and Metals & SURF Matching \\
\hline $\begin{array}{l}\text { 1. Implement and maintain ethical business practices and sound systems of corporate governance. } \\
\text { 2. Integrate sustainable development considerations within the corporate decision-making } \\
\text { process. }\end{array}$ & $\mathrm{S}, \mathrm{U}, \mathrm{R}, \mathrm{F}$ \\
\hline $\begin{array}{l}\text { 3. Uphold fundamental human rights and respect cultures, customs and values in dealings with } \\
\text { employees and others who are affected by our activities. }\end{array}$ & $\mathrm{R}, \mathrm{F}$ \\
\hline \begin{tabular}{l} 
4. Implement risk management strategies based on valid data and sound science. \\
\hline 5. Seek continual improvement of our health and safety performance.
\end{tabular} & $\mathrm{S}, \mathrm{U}, \mathrm{R}, \mathrm{F}$ \\
\hline $\begin{array}{l}\text { 6. Seek continual improvement of our environmental performance. } \\
\text { 7. Contribute to conservation of biodiversity and integrated approaches to land use planning. }\end{array}$ & $\mathrm{S}, \mathrm{U}, \mathrm{F}$ \\
\hline $\begin{array}{l}\text { 8. Facilitate and encourage responsible product design, use, re-use, recycling and disposal of our } \\
\text { products. }\end{array}$ & $\mathrm{S}, \mathrm{U}, \mathrm{F}$ \\
\hline $\begin{array}{l}\text { 9. Contribute to the social, economic and institutional development of the communities in which } \\
\text { we operate. }\end{array}$ & $\mathrm{S}, \mathrm{U}, \mathrm{R}, \mathrm{F}$ \\
\hline $\begin{array}{l}\text { 10. Implement effective and transparent engagement, communication and independently verified } \\
\text { reporting arrangements with our stakeholders. }\end{array}$ & $\mathrm{R}, \mathrm{F}$ \\
\hline
\end{tabular}

\section{References}

AccountAbility. (n.d.). Retrieved May 21, 2013, from http://www.accountability.org/standards/

Bebbington, J. (2006). Accounting for sustainable development performance. Research Executive Summaries Series, 2(15). St. Andrews: The Chartered Institute of Management Accountants.

Blekinge Institute of Technology. (2008, May). Guide to the Framework for Strategic Sustainable Development. Retrieved April 1, 2013, from Step: http://www.naturalstep.org/sites/all/files/Guide\%20to\%20the\%20FSSD.PDF

British Standards Institution, Forum for the Future, and AccountAbility. (2006). SIGMA Project-Sustainability-Integrated Guidelines for Management. Retrieved May 22, 2013, from http://www.projectsigma.co.uk/

Dow Jones. (n.d.). Dow Jones Sustainability Indices. Retrieved May 19, 2013, from http://www.sustainability-indices.com/dow-jones-sustainability-indices/index.jsp

Ellen MacArthur Foundation. (n.d.). Circular Economy. Retrieved May 11, 2013, from http://www.ellenmacarthurfoundation.org/circular-economy/circular-economy

Elliott, J. A. (2006). An Introduction to Sustainable Development. Abingdon: Routledge Taylor \& Francis Group.

Fenner, R. A., Ainger, C. M., Cruickshank, H. J., \& Guthrie, P. M. (2006). Widening engineering horizons: addressing the complexity of sustainable development. Engineering Sustainability, 159, 145-154. Proceedings of the Institution of Civil Engineers . http://dx.doi.org/10.1680/ensu.2006.159.4.145

FTSE. (2010). FTSE4Good Index Series. Retrieved May 21, 2013, from http://www.ftse.com/Indices/FTSE4Good_Index_Series/index.jsp

Global Footprint Network. (2011). The Global Footprint Network. Retrieved May 24, 2013, from Glossary: http://www.footprintnetwork.org/en/index.php/GFN/page/glossary/

Global Reporting Initiative. (n.d.). Global Reporting Initiative. Retrieved May 15, 2013, from https://www.globalreporting.org/Information/about-gri/Pages/default.aspx

Hamilton, B., Berk, S., \& Bundschuh, R. (2004). Soul Surfer A true Story of Faith, Family, and Fighting to Get Back on the Board. New York: Gallery Books.

Hoekstra, A. C. (2011). The water footprint assessment manual: Setting the global standard. Retrieved May 21, 
2013, from http://www.waterfootprint.org/downloads/TheWaterFootprintAssessmentManual.pdf

ICMM. (2003). Sustainable Development Framework. Retrieved March 31, 2013, from http://www.icmm.com/our-work/sustainable-development-framework/10-principles

IISD. (1992). Sustainable development: a business definition. Retrieved April 18, 2013, from Business strategies for sustainable development: http://www.iisd.org/business/pdf/business_strategy.pdf

International Council of Chemical Associations. (2013). Responsible Care. Retrieved May 22, 2013, from http://www.icca-chem.org/en/Home/Responsible-care/

International Organization for Standardization. (n.d.). Retrieved May 4, 2013, from http://www.iso.org/iso/home.html

Lawn, P. (2005). An Assessment of the Valuation Methods Used to Calculate the Index of Sustainable Economic Welfare (ISEW), Genuine Progress Indicator (GPI), and Sustainable Net Benefit Index (SNBI). Environment, Development and Sustainability, 7(2), 185-208. http://dx.doi.org/10.1007/s10668-005-7312-4

Leon H. Sullivan Foundation. (n.d.). The Global Sullivan Principles of Social Responsibility. Retrieved May 21, 2013, from http://thesullivanfoundation.org/about/global-sullivan-principles

Maathai, W. (2007). Unbowed. New York: Anchor.

McDonough, W., \& Braungart, M. (2002). Cradle to Cradle: Remaking the Way We Make THings. New York: North Point Press.

OECD. (n.d.). OECD Better Life Index. Retrieved April 5, 2013, from http://www.oecdbetterlifeindex.org/

OECD. (2011). OECD Guidelines for Multinational Enterprises. Retrieved May 22, 2013, from http://www.oecd.org/daf/inv/mne/oecdguidelinesformultinationalenterprises.htm

Pauli, G. (2013). The Blue Economy. Retrieved from http://theblueeconomy.org/blue/Home.html

Pearce, D. (1998). The Concept of Sustainable Development: An Evaluation of its Usefulness 10 Years After Bruntland. Retrieved June 24, 2012, from http://cserge.ac.uk/sites/default/files/pa_1998_02.pdf

Pisani, J. A. (2006). Sustainable development-historical roots of the concept. Environmental Sciences, 3(2), 83-96. http://dx.doi.org/10.1080/15693430600688831

Social Accountability International. (2012). SA8000 Standard: 2008. Retrieved May 21, 2013, from Social Accountability International: http://www.sa-intl.org/index.cfm?fuseaction=Page.ViewPage\&pageId=1458

Solow, R. (1993). An almost practical step toward sustainability. Resources Policy, 19(3), 162-172. http://dx.doi.org/10.1016/0301-4207(93)90001-4

Stahel, W. (1986). Hidden innovation. Science \& Public Policy, 13 (4).

Sustainable Society Foundation. (n.d.). Sustainable Society Index-your compass to sustainability. Retrieved May 21, 2013, from http://www.ssfindex.com/ssi/

The Natural Step. (n.d.). Backcasting. Retrieved May 21, 2013, from http://www.naturalstep.org/backcasting

The Natural Step. (n.d.). Our Approach - The Framework for Strategic Sustainable Development. Retrieved May 21, 2013, from http://www.naturalstep.org/our-approach

UNDP. (2013). Human Development Index . Retrieved May 21, 2013, from http://hdr.undp.org/en/statistics/hdi/

UNEP. (1991). Cleaner Production. Retrieved May 21, 2013, from http://www.unido.org/what-we-do/environment/resource-efficient-and-low-carbon-industrial-production/cp/ cleaner-production.html

UNEP. (n.d.). What is the Green Economy? Retrieved May 5, 2013, from http://www.unep.org/greeneconomy/AboutGEI/WhatisGEI/tabid/29784/Default.aspx

United Nations. (2012, June). The Future We Want. Retrieved from http://www.un.org/disabilities/documents/rio20_outcome_document_complete.pdf

United Nations. (n.d.). What is the UN Global Compact? Retrieved May 22, 2013, from http://www.unglobalcompact.org/

Ura, K., Alkire, S., Zangmo, T., \& Wangdi, K. (2012). A Short Guide to Gross National Happiness Index. Retrieved September 14, 2012 from The Centre for Bhutan Studies: http://www.grossnationalhappiness.com/wp-content/uploads/2012/04/Short-GNH-Index-final1.pdf 
USEPA. (n.d.). Glossary of Climate Change Terms. Retrieved May 24, 2013, from Carbon Footprint: $\mathrm{http} / / /$ www.epa.gov/climatechange/glossary.html\#C.

USEPA. (2012). Life Cycle Assessment (LCA). Retrieved May 24, 2013, from $\mathrm{http}: / / \mathrm{www} . e p a . g o v / \mathrm{nrmrl} / \mathrm{std} / \mathrm{lca} / \mathrm{lca} \cdot \mathrm{html}$

WBCSD. (n.d.). WBCSD Measuring Impact Framework . Retrieved May 22, 2013, from World Business Council for Sustainable Development: http://www.wbcsd.org/work-program/development/measuring-impact.aspx.

Wilson, J., \& Tyedmers, P. (2013). Rethinking What Counts. Perspectives on Wellbeing and Genuine Progress Indicator Metrics from a Canadian Viewpoint. Sustainability, 5, 187-202. http://dx.doi.org/10.3390/su5010187

Wisconsin Manufacturing Extension Partnership. (n.d.). Glossary of Lean Manufacturing Terms. Retrieved May 24, 2013, from http://www.wmep.org/next-generation-manufacturing/systemic-continuous-improvement/lean-manufacturin g-vsm-5s-tpm-twi-0

World Commission on Environment and Development. (1987). Our Common Future. Oxford: Oxford University Press.

Worthington, E. B. (1938). Science in Africa; a review of scientific research relating to tropical and southern Africa. London: Oxford University Press.

YCELP \& CIESIN. (2012). Yale Center for Environmental Law and Policy (YCELP) and the Center for Earth Information Science Information Network (CIESIN). Retrieved from Environmental Performance Index: http://envirocenter.yale.edu/programs/environmental-performance-management/environmental-performanc e-index/.

\section{Note}

Note 1.

\section{ISO Environmental Management Family}

- ISO 14001:2004 Environmental management systems-Requirements with guidance for use

- ISO 14004:2004 Environmental management systems-General guidelines on principles, systems and support techniques

- ISO 14006:2011 Environmental management systems - Guidelines for incorporating ecodesign

- ISO 14020:2000 Environmental labels and declarations-General principles

- ISO 14021:1999 Environmental labels and declarations-Self-declared environmental claims (Type II environmental labelling)

- ISO 14024:1999 Environmental labels and declarations-Type I environmental labelling-Principles and procedures

- ISO 14025:2006 Environmental labels and declarations-Type III environmental declarations - Principles and procedures

- ISO 14031:1999 Environmental management—Environmental performance evaluation — Guidelines

- ISO 14040:2006 Environmental management—Life cycle assessment—Principles and framework

- ISO 14044:2006 Environmental management—Life cycle assessment—Requirements and guidelines

- ISO/TR 14062:2002 Environmental management-Integrating environmental aspects into product design and development

- ISO 14063:2006 Environmental management—Environmental communication-Guidelines and examples

- ISO 14064-1:2006 Greenhouse gases-Part 1: Specification with guidance at the organization level for quantification and reporting of greenhouse gas emissions and removals

- ISO 14064-2:2006 Greenhouse gases-Part 2: Specification with guidance at the project level for quantification, monitoring and reporting of greenhouse gas emission reductions or removal enhancements

- ISO 14064-3:2006 Greenhouse gases-Part 3: Specification with guidance for the validation and verification 
of greenhouse gas assertions

- ISO/TR 14047:2012 Environmental management—Life cycle assessment-Illustrative examples on how to apply ISO 14044 to impact assessment situations

- ISO/TR 14049:2012 Environmental management-Life cycle assessment-Illustrative examples on how to apply ISO 14044 to goal and scope definition and inventory analysis

- ISO/TS 14048:2002 Environnemental management—Life cycle assessment—Data documentation format

\section{ISO Quality Management Family}

- ISO 9000:2005 Quality management systems-Fundamentals and vocabulary

- ISO 9001:2008 Quality management systems—-Requirements

- ISO 9004:2009 Managing for the sustained success of an organization-Aquality management approach

- ISO 19011:2011 Guidelines for auditing management systems

\section{OTHER}

- ISO 50001:2011 Energy management systems-Requirementswith guidance for use

- ISO 26000:2010 Guidance on social responsibility

\section{Copyrights}

Copyright for this article is retained by the author(s), with first publication rights granted to the journal.

This is an open-access article distributed under the terms and conditions of the Creative Commons Attribution license (http://creativecommons.org/licenses/by/3.0/). 